\title{
Insects related to Olive culture in Rio Grande do Sul State, Brazil
}

\author{
Insetos associados à cultura da oliveira no Rio Grande do Sul, Brasil
}

\author{
Marcelo Perrone Ricalde ${ }^{I}$ Dori Edson Nava ${ }^{I I}$ Alci Enimar Loeck ${ }^{\mathrm{I}}$ \\ Enilton Fick Coutinho ${ }^{\mathrm{II}}$ Alexandre Bisognin ${ }^{\mathrm{III}}$ Flávio Roberto Mello Garcia ${ }^{\mathrm{I}^{*}}$
}

ABSTRACT

The increased cultivation of olive trees in Rio Grande do Sul State and its potential production arouse the need to characterize the assemblage of insects in olive groves, especially those with potential as pests. Therefore, the insect fauna was sampled monthly for two years, in the canopy of olive trees, using beat cloth, and collection of buds in five municipalities in Southern Rio Grande do Sul State. The faunal indices analyzed were abundance, constancy, dominance and frequency. The olive caterpillar Palpita forficifera Munroe 1959 (Lepidoptera: Pyralidae) and mealybugs Saissetia oleae (Olivier, 1791) and Saissetia coffeae (Walker, 1952) (Hemiptera: Coccidae) are the main phytophagous insects in olive farms in the Rio Grande do Sul State, with potential to reach pest status. Eleven insect species were recorded for the first time in olive groves in Brazil. The occurrence of $\boldsymbol{P}$. forficifera is a new record for the Rio Grande do Sul State.

Key words: olive pests, monitoring, new insets records, olive caterpillar.

RESUMO

Tendo em vista o aumento do cultivo da oliveira no Rio Grande do Sul e o seu potencial produtivo, houve a necessidade de caracterizar a assembleia de insetos presentes em olivais, destacando os que possuem potenciais como praga da cultura. Para tanto, a fauna de insetos foi monitorada por meio de coletas mensais, durante o periodo de dois anos, na copa das oliveiras, utilizando pano de batida e coleta de brotos em cinco municípios da região sul do Rio Grande do Sul. Os índices faunísticos analisados foram abundância, constância, dominância e frequência. A lagarta-da-oliveira Palpita forficifera Munroe 1959 (Lepidoptera: Pyralidae) e as cochonilhas Saissetia oleae (Olivier, 1791) e Saissetia coffeae (Walker, 1952) (Hemiptera: Coccidae) são os principais insetos fitófagos na cultura da oliveira no Rio Grande do Sul, com potencial para atingir status de praga.
Foram registradas onze espécies de insetos pela primeira vez para a cultura no Brasil. A ocorrência de P. forficifera é um novo registro para o estado do Rio Grande do Sul.

Palavras-chave: pragas olivicultura, monitoramento, novos registros, lagarta da oliveira.

\section{INTRODUCTION}

The culture of olive tree (Olea europaea L.) was introduced in Brazil in the XIX century, but its commercial exploitation in the South and Southeast occurred only in the XXI century, due to research related to improving the cropping system and the choice of appropriate areas through the agroclimatic zoning (VILLA \& OLIVEIRA, 2012).

The olive was introduced in Brazil in various regions of the South and Southeast. Areas with commercial plantations in Rio Grande do Sul are located in the municipalities of Bagé, Cachoeira do Sul, Caçapava do Sul, Dom Pedrito, Encruzilhada do Sul, Rio Grande, Santana do Livramento and Vacaria. The cultivated area in these municipalities is over 600 hectares, with most varieties intended to produce oil. Despite the planting growth in recent years, little information is available about crop management, especially in relation to plant health problems due to recent commercial cultivation in Brazil (COUTINHO et al., 2009).

\footnotetext{
IDepartamento de Fitossanidade, Faculdade de Agronomia "Eliseu Maciel” (FAEM), Universidade Federal de Pelotas (UFPel), Campus Universitário, s/n, CP 354, 96077-170, Pelotas, RS, Brasil. E-mail: flaviormg@hotmail.com. "Corresponding author.

IIEmbrapa Clima Temperado (EMBRAPA/CPACT), Pelotas, RS, Brasil.

IIIFAEM, UFPel, Capão do Leão, RS, Brasil.
} 
A factor limiting the cultivation of olive trees is the attack of pests given the record of over 250 phytophagous species for this culture, among which $10 \%$ have economic importance. Losses caused by pests worldwide are estimated at more than $30 \%$ of production, including $15 \%$ which are caused by insects, generating an annual cost of over 100 million euros (KALAITZAKI \& NIKOS, 2005). Losses are not greater due mainly to predators of the orders Araneae, Neuroptera, Coleoptera and Hymenoptera (SANTOS et al., 2009).

In European countries where the olive tree is cultivated, almost all insect species related to culture are known. The major pests include the olive moth Prays oleae Bernard 1788 (Lepidoptera: Yponomeutidae) and olive fly Bactrocera oleae Rossi 1790 (Diptera: Tephritidae) (PATANITA \& REIS, 2007). In Brazil, there is still a little known about arthropods associated with olive, only the studies of PRADO \& SILVA (2006), CHIARADIA \& DA CROCE (2008), CORDEIRO et al. (2012), RICALDE et al. (2012), RICALDE \& GARCIA (2013), have addressed this subject. Therefore this research is the first survey of insects associated with the cultivation of olive in the Rio Grande do Sul State. Considering the beginning of olive cultivation in the Rio Grande do Sul State and its production potential, the goal was to investigate the insect assemblage in olive groves in the Rio Grande do Sul State.

\section{MATERIAL AND METHODS}

Sampling was conducted monthly from October 2010 to October 2012, in five olive groves located in five municipalities in the Rio Grande do Sul State, and characterized according to table 1 . The insect fauna was sampled in the treetops, using beat cloth according to the methodology described by REI (2006) except for collecting thrips, in which it was used a white tray according to BOTTON et al.
(2007). Two beats per tree were made on 20 plants per olive grove, one in the shaded side and another on the sunny side. Specimens collected were placed in pots containing $70 \%$ alcohol, properly labeled.

In the same periodand olive groves, it was collected 20 buds per grove for sampling insects. Buds were randomly collected and placed in paper bags and sent to the Laboratory of Insect Ecology of the UFPel, for checking the presence of insects using a stereoscopic microscope. Some species of insects, which were collected and were causing damage, were identified to the species level by experts specialized in the taxonomic group.

After identification, data were used for faunal analysis, determining the indices of frequency (THOMAZINI \& THOMAZINI, 2002), constancy (SILVEIRANETO et al., 1976), abundance (GARCIA \& CORSEUIL 1998) and dominance (SILVA, 1993). The faunal indices were calculated with the aid of the Anafau $^{\circledR}$ software. Among the phytophagous insects collected stood out those with potential as pest in olive groves of the Rio Grande do Sul State.

\section{RESULTS AND DISCUSSION}

The family Pentatomidae (Hemiptera) showed the largest number of species collected, occurring in all municipalities. Nezara viridula (Linnaeus 1758) was dominant in Santana do Livramento and in Pelotas, as well as Loxa deducta (Walker, 1867) in Rio Grande. The other species collected were: Oebalus ypsilongriseus (De Geer, 1773), Podisus distinctus (Stål, 1860), Podisus nigrispinus (Dallas, 1851), Piezodorus guildini (Westwood, 1837), Dichelops furcatus (Fabricius, 1775), Chinavia armigera (Stål, 1859) and Olbia elegans (Herrich-Schäffer, 1839), which were infrequent and accidental. In India, $\boldsymbol{N}$. viridula has already been recorded attacking olive plants (KAUL et al., 2007). In Australia, this species is found in olive groves damaging the fruits (SPOONER-

Table 1 - Location of areas where the collections of insects and mites were held in Rio Grande do Sul, with their cultivated areas, spacing, age and cultivars.

\begin{tabular}{|c|c|c|c|c|c|}
\hline Municipalities & Location & Area (ha) & Spacing $(\mathrm{m})$ & Age (years) & Cultivars \\
\hline Pelotas (Plt) & 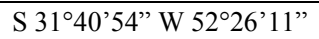 & 2 & $6 \times 6$ & $4-5$ & $1,2,3,4,5,6$ \\
\hline Bagé (Bge) & S $31^{\circ} 08^{\prime} 44^{\prime \prime} \mathrm{W} 54^{\circ} 11^{\prime} 42^{\prime \prime}$ & 2 & $7 \times 2,80$ & $4-5$ & $1,2,3,4,5,6$ \\
\hline Rio Grande (Rgr) & S $31^{\circ} 08^{\prime} 42^{\prime \prime} \mathrm{W} 54^{\circ} 11^{\prime} 45^{\prime \prime}$ & 1,5 & $10 \times 5$ & +40 & 7 \\
\hline Cachoeira do Sul (Ccr) & $\mathrm{S} 30^{\circ} 00^{\prime} 30^{\prime \prime} \mathrm{W} 52^{\circ} 51^{\prime} 53^{\prime \prime}$ & 40 & $6 \times 4$ & $4-5$ & $1,2,3,4,5,6$ \\
\hline Santana do Livramento (Siv) & $\mathrm{S} 31^{\circ} 08^{\prime} 42^{\prime \prime} \mathrm{W} 54^{\circ} 11^{\prime} 45^{\prime \prime}$ & 20 & $7 \times 4$ & $2-3$ & $1,2,3,4,5,6$ \\
\hline
\end{tabular}

*Cultivars: 1-‘Arbequina'; 2-‘Arbosana'; 3-'Koroneiki’; 4-‘Frantoio'; 5-‘Manzanilla’; 6- 'Picual'; 7-‘Galega'. 
HART et al., 2007). In this study, it was not observed damage to fruit.

Coccidia are the main insects that can reach pest status in the olive culture, especially Saissetia oleae (Olivier, 1791) and Saissetia coffeae (Walker,
1952). According to PRADO \& SILVA (2006), the mealybug $S$. oleae is among the most important pests because it causes direct and indirect damage and can reduce flowering, fruiting and quality of olives (CHIARADIA \& DA CROCE, 2008). The mealybug

Table 2 - Faunal analysis of the insect assemblage collected by beat cloth and sampling of buds in olive groves of five municipalities of the Rio Grande do Sul State.

\begin{tabular}{|c|c|c|c|c|c|c|c|c|c|c|c|c|c|c|c|c|c|c|c|c|}
\hline \multirow{2}{*}{ Species } & \multicolumn{20}{|c|}{--------- Abundance --------- ---------- Constancy --------- --------- Dominance ------- --------- Frequency ------ } \\
\hline & Plt & Ccr & Bge & Siv & Rgr & Plt & Ccr & Bge & Siv & Rgr & Plt & Ccr & Bge & Siv & Rgr & Plt & Ccr & Bge & Siv & Rgr \\
\hline Hemiptera & & & & & & & & & & & & & & & & & & & & \\
\hline Saissetia coffeae & $\mathrm{c}$ & ma & $\mathrm{c}$ & $\mathrm{c}$ & $\mathrm{Ma}$ & Z & W & W & W & W & ND & $\mathrm{D}$ & $\mathrm{D}$ & $\mathrm{D}$ & $\mathrm{D}$ & $\mathrm{F}$ & MF & $\mathrm{F}$ & $\mathrm{F}$ & MF \\
\hline $\begin{array}{l}\text { Saissetia oleae } \\
\text { Quadraspidiotus }\end{array}$ & $\mathrm{ma}$ & ma & $\mathrm{c}$ & $\mathrm{a}$ & $\mathrm{Ma}$ & W & W & W & W & W & $\mathrm{D}$ & $\mathrm{D}$ & $\mathrm{D}$ & $\mathrm{D}$ & $\mathrm{D}$ & $\mathrm{MF}$ & MF & $\mathrm{F}$ & $\mathrm{MF}$ & MF \\
\hline perniciosus & - & - & - & - & $\mathrm{Ma}$ & - & - & - & - & Z & - & - & - & - & $\mathrm{D}$ & - & - & - & - & MF \\
\hline Gargara. genistae & $\mathrm{r}$ & - & - & - & - & $\mathrm{Z}$ & - & - & - & - & ND & - & - & - & - & $\mathrm{PF}$ & - & - & - & - \\
\hline Chinavia armigera & - & - & - & - & $\mathrm{R}$ & - & - & - & - & $\mathrm{Z}$ & - & - & - & - & ND & - & - & - & - & $\mathrm{PF}$ \\
\hline Dichelops furcatus & - & d & d & - & - & - & Z & Z & - & - & - & ND & ND & - & - & - & PF & PF & - & - \\
\hline Loxa deducta & $\mathrm{c}$ & $\mathrm{d}$ & $\mathrm{c}$ & - & $\mathrm{R}$ & W & $\mathrm{Y}$ & $\mathrm{Y}$ & - & $\mathrm{Y}$ & $\mathrm{D}$ & ND & ND & - & $\mathrm{D}$ & $\mathrm{F}$ & PF & $\mathrm{F}$ & - & $\mathrm{PF}$ \\
\hline Nezara viridula & d & - & $\mathrm{d}$ & $\mathrm{c}$ & - & $\mathrm{Y}$ & - & Z & Z & - & ND & - & ND & $\mathrm{D}$ & - & $\mathrm{PF}$ & - & $\mathrm{PF}$ & $\mathrm{F}$ & - \\
\hline Oebalus ypsilongriseus & - & - & - & $\mathrm{d}$ & - & - & - & - & $\mathrm{Z}$ & - & - & - & - & ND & - & - & - & - & $\mathrm{PF}$ & - \\
\hline Olbia elegans & - & - & - & - & $\mathrm{R}$ & - & - & - & - & $\mathrm{Z}$ & - & - & - & - & ND & - & - & - & - & $\mathrm{PF}$ \\
\hline Piezodorus guildini & $\mathrm{d}$ & d & $\mathrm{d}$ & - & - & $\mathrm{Y}$ & Z & $\mathrm{Z}$ & - & - & ND & ND & ND & - & - & $\mathrm{PF}$ & $\mathrm{PF}$ & $\mathrm{PF}$ & - & - \\
\hline Podisus distinctus & $\mathrm{r}$ & - & - & - & - & $\mathrm{Z}$ & - & - & - & - & ND & - & - & - & - & $\mathrm{PF}$ & - & - & - & - \\
\hline Podisus nigrispinus & $\mathrm{d}$ & - & - & - & - & $\mathrm{Y}$ & - & - & - & - & ND & - & - & - & - & $\mathrm{PF}$ & - & - & - & - \\
\hline Pyrrhocoridae & - & - & $\mathrm{d}$ & $\mathrm{d}$ & $\mathrm{R}$ & - & - & $\mathrm{Y}$ & $\mathrm{Z}$ & $\mathrm{Z}$ & - & - & ND & ND & ND & - & - & $\mathrm{PF}$ & $\mathrm{PF}$ & $\mathrm{PF}$ \\
\hline Zellus sp. & $\mathrm{c}$ & - & - & - & - & Z & - & - & - & - & $\mathrm{D}$ & - & - & - & - & $\mathrm{F}$ & - & - & - & - \\
\hline $\begin{array}{l}\text { Reduviidae } \\
\text { Thysanoptera }\end{array}$ & - & $\mathrm{c}$ & d & $\mathrm{c}$ & - & - & $\mathrm{Y}$ & $\mathrm{Y}$ & $\mathrm{Z}$ & - & - & $\mathrm{D}$ & ND & ND & - & - & $\mathrm{F}$ & $\mathrm{PF}$ & $\mathrm{F}$ & - \\
\hline Frankliniella schultzei & - & - & $d$ & $\mathrm{c}$ & - & - & - & Z & $\mathrm{Z}$ & & - & - & ND & $\mathrm{D}$ & - & - & - & $\mathrm{PF}$ & $\mathrm{F}$ & - \\
\hline $\begin{array}{l}\text { Thrips tabaci } \\
\text { Neuroptera }\end{array}$ & - & - & $\mathrm{c}$ & - & - & - & - & $\mathrm{Z}$ & - & & - & - & $\mathrm{D}$ & - & - & - & - & $\mathrm{F}$ & - & - \\
\hline $\begin{array}{l}\text { Chrysoperla } \mathrm{sp} . \\
\text { Coleoptera }\end{array}$ & $\mathrm{d}$ & $\mathrm{c}$ & $\mathrm{c}$ & $\mathrm{c}$ & $\mathrm{R}$ & $\mathrm{Y}$ & Y & W & $\mathrm{Y}$ & $\mathrm{Y}$ & ND & ND & ND & ND & ND & $\mathrm{PF}$ & $\mathrm{PF}$ & $\mathrm{F}$ & $\mathrm{F}$ & $\mathrm{PF}$ \\
\hline Diabrotica speciosa & $\mathrm{ma}$ & $\mathrm{d}$ & $\mathrm{d}$ & $\mathrm{d}$ & $\mathrm{C}$ & W & $\mathrm{Z}$ & $\mathrm{Z}$ & $\mathrm{Y}$ & W & $\mathrm{D}$ & ND & ND & ND & $\mathrm{D}$ & MF & $\mathrm{PF}$ & $\mathrm{PF}$ & $\mathrm{PF}$ & $\mathrm{F}$ \\
\hline Astylus quadrilineatus & - & ma & - & - & - & - & $\mathrm{Z}$ & - & - & - & - & $\mathrm{D}$ & - & - & - & - & MF & - & - & - \\
\hline Astylus variegatus & $\mathrm{c}$ & d & $\mathrm{d}$ & - & - & $\mathrm{Z}$ & Z & $\mathrm{Z}$ & - & - & $\mathrm{D}$ & ND & ND & - & - & $\mathrm{F}$ & $\mathrm{PF}$ & $\mathrm{PF}$ & - & - \\
\hline Cycloneda sanguinea & $\mathrm{r}$ & $\mathrm{c}$ & d & $\mathrm{d}$ & - & $\mathrm{Z}$ & $\mathrm{Y}$ & W & Z & - & ND & ND & ND & ND & - & $\mathrm{PF}$ & $\mathrm{F}$ & $\mathrm{PF}$ & $\mathrm{PF}$ & - \\
\hline Eriopis conexa & $d$ & d & d & $\mathrm{c}$ & - & $\mathrm{Z}$ & Z & $\mathrm{Z}$ & $\mathrm{Y}$ & - & ND & ND & ND & $\mathrm{D}$ & - & $\mathrm{PF}$ & $\mathrm{PF}$ & $\mathrm{PF}$ & $\mathrm{F}$ & - \\
\hline Harmonia axyridis & $\mathrm{c}$ & $\mathrm{c}$ & - & - & $\mathrm{R}$ & W & $\mathrm{Y}$ & - & - & $\mathrm{Z}$ & $\mathrm{D}$ & ND & - & - & ND & $\mathrm{F}$ & $\mathrm{F}$ & - & - & $\mathrm{PF}$ \\
\hline Olla sp. & $\mathrm{r}$ & - & - & - & - & $\mathrm{Z}$ & - & - & - & - & ND & - & - & - & - & $\mathrm{PF}$ & - & - & - & - \\
\hline Olla v-nigrun & $\mathrm{r}$ & $d$ & - & $\mathrm{d}$ & $\mathrm{C}$ & $\mathrm{Z}$ & $\mathrm{Z}$ & - & $\mathrm{Y}$ & $\mathrm{Z}$ & ND & ND & - & ND & $\mathrm{D}$ & $\mathrm{PF}$ & $\mathrm{PF}$ & - & $\mathrm{PF}$ & $\mathrm{F}$ \\
\hline Naupactus sp. & $\mathrm{r}$ & - & - & - & - & $\mathrm{Z}$ & - & - & - & - & ND & - & - & - & - & $\mathrm{PF}$ & - & - & - & - \\
\hline Cantharidae & $\mathrm{c}$ & - & - & - & $\mathrm{Ma}$ & $\mathrm{Y}$ & - & - & - & $\mathrm{Y}$ & ND & - & - & - & $\mathrm{D}$ & $\mathrm{F}$ & - & - & - & MF \\
\hline $\begin{array}{l}\text { Elateridae } \\
\text { Diptera }\end{array}$ & $\mathrm{d}$ & - & $\mathrm{a}$ & $\mathrm{d}$ & $\mathrm{R}$ & $\mathrm{Y}$ & - & W & $\mathrm{Z}$ & Z & ND & - & $\mathrm{D}$ & ND & ND & $\mathrm{PF}$ & - & $\mathrm{MF}$ & $\mathrm{PF}$ & $\mathrm{PF}$ \\
\hline $\begin{array}{l}\text { Anastrepha daciformis } \\
\text { Lepidoptera }\end{array}$ & - & $\mathrm{d}$ & - & - & - & - & $\mathrm{Z}$ & - & - & - & - & ND & - & - & - & - & $\mathrm{PF}$ & - & - & - \\
\hline $\begin{array}{l}\text { Palpita forficifera } \\
\text { Argyrotaenia }\end{array}$ & $\mathrm{ma}$ & $\mathrm{ma}$ & $\mathrm{ma}$ & $\mathrm{ma}$ & $\mathrm{Ma}$ & W & W & W & W & W & $\mathrm{D}$ & $\mathrm{D}$ & $\mathrm{D}$ & $\mathrm{D}$ & $\mathrm{D}$ & $\mathrm{MF}$ & $\mathrm{MF}$ & MF & $\mathrm{MF}$ & $\mathrm{MF}$ \\
\hline $\begin{array}{l}\text { sphaleropa } \\
\text { Hymenoptera }\end{array}$ & - & - & $\mathrm{c}$ & - & - & - & - & $\mathrm{Y}$ & - & - & - & - & $\mathrm{D}$ & - & - & - & - & $\mathrm{F}$ & - & - \\
\hline Dorymyrmex sp. & $\mathrm{c}$ & d & - & $\mathrm{c}$ & $\mathrm{D}$ & $\mathrm{Y}$ & $\mathrm{Z}$ & - & $\mathrm{Y}$ & $\mathrm{Z}$ & $\mathrm{D}$ & ND & - & $\mathrm{D}$ & $\mathrm{D}$ & $\mathrm{F}$ & $\mathrm{PF}$ & - & $\mathrm{F}$ & $\mathrm{PF}$ \\
\hline Camponotus sp. & - & - & - & - & $\mathrm{Ma}$ & - & - & - & - & W & - & - & - & - & $\mathrm{D}$ & - & - & - & - & MF \\
\hline Acromyrmex striatus & $\mathrm{c}$ & - & - & - & $\mathrm{R}$ & $\mathrm{Z}$ & - & - & - & $\mathrm{Z}$ & $\mathrm{D}$ & - & - & - & $\mathrm{D}$ & $\mathrm{F}$ & - & - & - & $\mathrm{PF}$ \\
\hline $\begin{array}{l}\text { Acromyrmex laticeps } \\
\text { Acromyrmex }\end{array}$ & - & - & - & - & $\mathrm{C}$ & - & - & - & - & $\mathrm{Z}$ & - & - & - & - & $\mathrm{D}$ & - & - & - & - & $\mathrm{F}$ \\
\hline crassispinus & - & - & - & - & $\mathrm{R}$ & - & - & - & - & $\mathrm{Z}$ & - & - & - & - & $\mathrm{D}$ & - & - & - & - & $\mathrm{PF}$ \\
\hline Acromyrmex lundi & - & - & $\mathrm{c}$ & - & $\mathrm{R}$ & - & - & $\mathrm{Z}$ & - & $\mathrm{Z}$ & - & - & ND & - & $\mathrm{D}$ & - & - & $\mathrm{F}$ & - & $\mathrm{PF}$ \\
\hline Acromyrmex ambiguus & $\mathrm{c}$ & - & $\mathrm{d}$ & - & $\mathrm{R}$ & $\mathrm{Z}$ & - & $\mathrm{Z}$ & - & $\mathrm{Z}$ & $\mathrm{D}$ & - & ND & - & ND & $\mathrm{F}$ & - & $\mathrm{PF}$ & - & $\mathrm{PF}$ \\
\hline
\end{tabular}

*Ma = Very abundant; $\mathrm{c}=$ Common; $\mathrm{d}=$ Dispersed; $\mathrm{r}=$ Rare; $\mathrm{W}=$ Constant; $\mathrm{Y}=$ Acessory; $\mathrm{Z}=$ Accidental; $\mathrm{D}=\mathrm{Dominant}$; $\mathrm{N}=\mathrm{Non}-\mathrm{Dominant}$; $\mathrm{MF}=$ Very Frequent; F= Frequent; PF= Infrequent, Plt - Pelotas, Ccr - Cachoeira do Sul, Bge, - Bagé, Siv- Santana do Livramento, Rgr - Rio Grande.

Ciência Rural, v.45, n.12, dez, 2015. 
S. oleae was dominant, very abundant, very frequent and constant (Table 2), occurring in all months of the year and in all municipalities. Similar result was obtained in Spain, in olive groves evaluated for buds and branches, with the occurrence of $\boldsymbol{S}$. oleae as a major pest (NOGUERA et al., 2003).

It was collected 102 individuals of $S$. coffeae, which was considered dominant, very abundant, very frequent and constant (Table 2). The wide distribution of $\boldsymbol{S}$. coffeae on olive growing regions can be attributed to its polyphagia, which allows it to adapt to different hosts (CONTRERAS et al., 2009).

Among Diaspididae, it was found only 35 specimens of Quadraspidiotus perniciosus (Comstock, 1881) (Table 2), which was considered a dominant, common, frequent and constant species, in an orchard with over 40 years of age in the municipality of Rio Grande. Nevertheless, it is an insect with low dispersal ability and usually attacks in outbreaks. Its economic importance is low in the groves (ALSTON et al., 2011). In regions with mild winter, $\boldsymbol{Q}$. perniciosus is found throughout the year, which does not occur in the Rio Grande do Sul State, given the low temperatures in winter (ALSTON et al., 2011). Its presence in olive trees has not yet been reported.

Moreover, two species of thrips were collected: Frankliniella schultzei (Trybom, 1910) and Thrips tabaci (Lindemann, 1888) (Thysanoptera: Thripidae). The first species occurred in the municipalities of Bagé and Santana do Livramento, being dominant in this latter. In turn, T. tabaci was recorded in Bagé, and although dominant, both species were accidental, once were concentrated only in the two municipalities. In Brazil, thrips are found in olive groves but without causing economic damage (CORDEIRO et al., 2012). In Europe, T. tabaci was reported causing damage to crop (ORTIZ, 1980).

It was also observed the species of the genus Chrysoperla, which, according to REI (2006) is responsible for the natural biological control of mealybugs, caterpillars, thrips, leafhoppers and mites in olive groves. In olive groves in Portugal, some species of Chrysopidae have an important role as biological control agents (SANTOS et al., 2009). Chrysoperla sp. occurred in all the groves, but was not dominant and not frequent in most groves. In Argentina, this species is used for the biological control of $\boldsymbol{S}$. oleae (MURÚA \& FIDALGO, 2001), and in Peru, it is reported consuming eggs and caterpillars of Palpita persimilis Munroe, 1959 (Lepidoptera: Crambidae) (LAZO et al., 2008)

Most coleopterans in olive groves belong to the guild of predator and pollinator entomophagous, being only one phytophagous species. The species Diabrotica speciosa (Germar, 1824) (Coleoptera: Chrysomelidae) was collected in all sampled groves, but only in the municipalities of Pelotas and Rio Grande, it was dominant, but no damage was observed in the culture.

Astylus quadrilineatus (Germar, 1825) of the family Melyridae was sampled only in the municipality of Cachoeira do Sul, as dominant, very abundant, very frequent and accidental, collected in large quantities only in the flowering period of olive trees. However, Astylus variegatus (Germar, 1824) occurred in the municipalities of Pelotas, Cachoeira do Sul and Bagé, as dominant and frequent only in the first and accidental in the others. In Argentina, A. quadrilineatus was observed pollinating plants of Cypella herbertii Landl and Alophia lahue (Molina) (Asparagales: Iridaceae) (DEVOTO \& MEDAN, 2008). This is the first occurrence of $\boldsymbol{A}$. quadrilineatus and $A$. variegatus in olive trees as potential pollen vector.

It was also collected five coccinellids, among them, Harmonia axyridis (Pallas, 1773) was found in the municipalities of Pelotas, Cachoeira do Sul and Rio Grande, being dominant only in the first. Olla sp. occurred only in Pelotas as non-dominant, rare, infrequent and accidental; Olla v-nigrum (Mulsant, 1866) occurred in most municipalities, except for Bagé, and was dominant only in Rio Grande. The species Cycloneda sanguinea (Linnaeus, 1763) occurred in most municipalities, with exception of Rio Grande, but with low frequency and low dominance. Eriops conexa (Germar, 1824) was dominant in Santana do Livramento and did not occur in Rio Grande. The family Coccinelidae exhibits great variability of species between regions and olive groves (REI, 2006).

Coccinellids were observed preying on mites and mealybugs. For REI (2006), this family of predators is one of the most important and present in most olive groves, and with increased presence, it appears a decrease in the population of $\boldsymbol{S}$. oleae, which was not observed in the samplings performed.

Considering the family Curculionidae, Naupactus sp. occurred only in Pelotas, where it was accidental and infrequent. Elateridae occurred in Pelotas and Rio Grande, in this latter it was dominant, very abundant, very frequent and accessory. These families showed no damage to the crop.

The family Cantharidae occurred in most municipalities, with the exception of Cachoeira do Sul. This family was dominant, abundant, very frequent and constant in Bagé, in the others it was infrequent. Similarly, REI (2006) observed a reduced presence of Cantharidae 
in Portuguese olive groves, without potential damage to culture, and its presence was accidental.

The only fly species collected was Anastrepha daciformis Bezzi, 1909 (Diptera: Tephritidae), collected in Cachoeira do Sul, on the treetop, as infrequent or accidental. It should be noted that this species does not attack $\boldsymbol{O}$. europeae L. and, moreover, there was no injuries caused by dipterans in the olive groves. In the meanwhile, the main pest is Bactrocera oleae Rossi 1790 (Diptera: Tephritidae), which causes great losses (PATANITA \& REIS, 2007), whose introduction in the country would entail a series of economic and environmental damage.

The authors also collected two species:

Palpita forficifera Munroe 1959 (Pyralidae) and Argyrotaenia sphaleropa (Meyrick, 1909) (Tortricidae). The caterpillar $\boldsymbol{P}$. forficifera is a potential pest of this crop (PRADO \& SILVA, 2006). The eggs were found in the olive branches and leaves. The caterpillars preferably feed on the buds, the damage occurs by reduced leaf area and, consequently, in the production of olives in the following year, as these buds give rise to fruit next year. Pupa remains between the junction of leaves tied together with silk.

In this study, $263 \boldsymbol{P}$. forficifera catterpillars were collected. This species was considered dominant, very abundant, very frequent and constant (Table 2), occurring from September to May. The importance of this caterpillar was reported in several countries in South America and Europe (CORDEIRO et al., 2012). In Brazil, $\boldsymbol{P}$. perssimilis had already been reported in the states of Santa Catarina (CHIARADIA \& DA CROCE, 2008) and Minas Gerais (CORDEIRO et al., 2012). In the Rio Grande do Sul State, this is the first record of $\boldsymbol{P}$. forficifera in olive groves.

In addition to $\boldsymbol{P}$. forficifera, the tortricid moth A. sphaleropa cause harm to the culture through the consumption of the plant tissue of young leaves and buds. This species had already been found in other hosts such as apple (Malus domestica Brork.), grapevine (Vitis vinifera L.), pear (Pyrus communis L.), persimmon (Diospyrus kaki L.), rose (Rosa sp. L.), ligustre (Ligustrum lucidum Ait.), jasmine (Gardenia jasminoides Vei.), Japanese honeysuckle (Lonicera japonica Thunb.), peach (Prunus persica L.) and citrus (Citrus sinensis) (NAVA et al., 2005).

The main losses in temperate fruit trees caused by $\boldsymbol{A}$. sphaleropa are due to the attack of caterpillars that scrape the skin of the fruit and leaves, reducing photosynthetic capacity and fruit quality (BOTTON et al., 2003). This damage was registered in young leaves and buds. The occurrence of this species in olive trees arouses the attention of researchers for possible economic damage to the crop. Seven species of ants were collected both in seedlings and in adult plants of olive trees. These animals caused severe damage in some plants during installation, causing the death of some specimens. Leaf-cutting ant species sampled in the olive groves were Acromyrmex crassispinus Forel, 1909, Acromyrmex laticeps Emery, 1905, Acromyrmex lundii (Guérin, 1838), Acromyrmex striatus (Roger, 1863) and Acromyrmex ambiguus Emery, 1887. These species have been registered for the Rio Grande do Sul State (LOECK et al., 2003). Thus, this is the first record of leaf-cutting ants of the genus Acromyrmex on olive crops in Brazil.

Besides the leaf-cutting ants, it was also found Camponotus sp. ants in facultative mutualism with mealybugs of the species $\boldsymbol{S}$. oleae. Despite being collected in the municipality of Rio Grande, this species was registered in all olive groves associated with mealybugs, which had been found by CHIARADIA \& DA CROCE (2008) in Santa Catarina State. According to PEREIRA et al. (2002), the presence of Camponotus sp. in Portuguese olive groves was associated with mealybugs, but also associated with predation on insects, like olive moth Prays oleae Bernard, 1788 (Lepidoptera: Yponomeutidae), and Euphyllura olivina (Costa, 1839) (Hemiptera: Psyllidae).

It was also assessed the location of the insects on the plant being collected only in shoots: Frankliniella schultzei, Thrips tabaci, Palpita forficifera and Argyrotaenia sphaleropa; the old leaves and branches: Anastrepha daciformis, Chrysoperla sp., Quadraspidiotus perniciosus, Gargara genistae, Chinavia armigera, Dichelops furcatus, Loxa deducta, Nezara viridula, Oebalus ypsilongriseus, Olbia elegans, Piezodorus guildini, Podisus distinctus, Podisus nigrispinus, Pyrrhocoridae, Zellus sp., Reduviidae, Diabrotica speciosa, Astylus quadrilineatus, Astylus variegatus, Naupactus sp., Cantharidae and Elateridae; both: Saissetia coffeae, Saissetia oleae, Cycloneda sanguinea, Eriopis conexa, Harmonia axyridis, Olla sp., Olla v-nigrun, Dorymyrmex sp., Camponotus sp., Acromyrmex striatus, Acromyrmex laticeps, Acromyrmex crassispinus, Acromyrmex lundi and Acromyrmex ambiguus.

Comparing the five olive groves, it can be highlighted three main insects, regardless of age and olive spacing that were important and deserve special attention from producers, the caterpillar Palpita forficifera and mealybugs Saissetia oleae 
and $\boldsymbol{S}$. coffeae, can be found and often cause economic damages in other producing countries (NOGUERA et al., 2003; CONTRERAS et al., 2009; CORDEIRO et al., 2012).

\section{CONCLUSIONS}

The predominant species in all olive groves were $\boldsymbol{P}$. forficifera and the mealybugs $\boldsymbol{S}$. oleae and $\boldsymbol{S}$. coffeae. Olive caterpillar $\boldsymbol{P}$. forficifera and the mealybugs $\boldsymbol{S}$. oleae and $\boldsymbol{S}$. coffeae are the main phytophagous insects in olive crops in the Rio Grande do Sul State, with potential to reach pest status. Species recorded for the first time in Brazilian olive groves are: Q. perniciosus, A. quadrilineatus, A. variegatus, $F$. schultzei and T. tabaci, A. sphaleropa, A. crassispinus, A. laticeps, $A$. lundii, $A$. striatus and $A$. ambiguus.

\section{REFERENCES}

ALSTON, D.G. et al. San Jose Scale (Quadraspidiotus perniciosus). Utah Pests, Fact Sheet, v.153, n.6, 5p. 2011.

BOTTON, M. et al. Avaliação de inseticidas para o controle de Frankliniella rodeos (Moulton, 1933) (Thysanoptera: Thripidae) em uva de mesa no Brasil. Boletín de Sanidad Vegetal Plagas, v.33, n.4, p.575-580, 2007

BOTTON, M. et al. Ocorrência de Argyrotaenia sphaleropa (Meyrick) (Lepidoptera: Tortricidae) danificando pêssegos na Serra Gaúcha, Rio Grande do Sul. Neotropical Entomology, v.32, n.3, p.503-505, 2003. Available from: <http://dx.doi.org/10.1590/ S1519-566X2003000300020>. Accessed: Apr. 20, 2014. doi: $10.1590 / \mathrm{S} 1519-566 \mathrm{X} 2003000300020$

CHIARADIA, L.A.; CROCE, D.M. Caracterização, danos e manejo de pragas da oliveira. Agropecuária Catarinense, v.21, p.53-55, 2008.

CONTRERAS, F.C. et al. Seminario manejo agronomico industrial olivicola. Vallenar: Instituto de Investigaciones Agropecuarias, 2009. 91p.

DEVOTO, M.; MEDAN, D. Expected mating system, floral diversity and flower visitors of five species of Iridaceae of the Argentine Pampas. Acta Botánica Venezuelica, v.31, n.2, p.425434, 2008.

GARCIA, F.R.M.; CORSEUIL, E. Análise faunística de moscasdas-frutas (Diptera, Tephritidae) em pomares de pessegueiro em Porto Alegre, Rio Grande do Sul. Revista Brasileira de Zoologia, v.15, n.4, p.1111-1117, 1998.

KALAITZAKI, A.; NIKOS, M. Integrated protection of olive crops. IOBC/WPRS Buletin, v.28, n.9, p.17-21, 2005.

KAUL, V. et al. Green stink bug (Hemiptera: Pentatomidae) recorded as a new pest of olive in India. Journal of Asian-Pacific Entomology, v.10, n.1, p.81-83, 2007. Available from: <http:// dx.doi.org/10.1016/S1226-8615(08)60335-0>. Accessed: Mar. 17, 2014. doi: 10.1016/S1226-8615(08)60335-0.

LAZO, D.C. et al. El cultivo del olivo en los valles de Caravelí. Lima: DESCO - Centro de Estudios y Promoción del Desarrollo, 2008. 44p.

LOECK, A.E. et al. Ocorrência de formigas cortadeiras do gênero Acromyrmex nas principais regiões agropecuárias do Rio Grande do Sul. Revista Brasileira de Agrociência, v.9, n.2, p.129-133, 2003.
MURÚA, M.G.; FIDALGO, P. Listado preliminar de los enemigos naturales de Saissetia oleae (Homoptera: Coccidae) en olivares de la província de La Rioja, Argentina. Boletín de Sanidad Vegetal Plagas, v.27, p.447-454, 2001

NAVA, D.E. et al. Microlepidópteros pragas dos citros: bioecologia, danos e controle. Piracicaba: ESALQ, 2005. 8p.

NOGUERA, V. et al. Ciclo biológico, dinámica poblacional y enemigos naturales de Saissetia oleae Olivier (Homoptera: Coccidae), en olivares del Alto Palancia (Castellón). Boletín de Sanidad Vegetal Plagas, v.29, p.495-504, 2003.

ORTIZ, M.S. Thrips tabaci Lindeman como problema en plantaciones de olivo. Revista Peruana de Entomologia, v.23, n.1, p.1-167, 1980.

PATANITA, M.I.; REIS, J. Monitoring of the main pests of olive in Alentejo (Portugal). In: INTERNATIONAL CONGRESSO OF CROP PROTECTION, 59., 2007, Bragança,. Proceedings... Bragança, International Organisation for Biological Control, 2007. 141.

PEREIRA, J.A. et al. Estudo preliminar sobre as formigas (Hymenoptera: Formicidae) associadas ao olival da Terra Quente Transmontana (Nordeste de Portugal). Boletín de Sanidad Vegetal Plagas, v.28, p.357-365, 2002.

PRADO, E.; SILVA, R.A. Principais pragas da oliveira: biologia e manejo. Informe Agropecuário Epamig, v.27, n.231, p.79-83, 2006.

REI, F.M. de C.T. A artropodofauna associada ao olival no âmbito da proteção de cultura contra pragas. 2006. $297 \mathrm{f}$. Tese (Doutorado em Entomologia Agrícola) - Universidade de Trás-osMontes e Alto Douro.

RICALDE, M.P. et al. Oxycenus maxwelli (Keifer) (Acari: Eriophyidae) danificando a cultura da oliveira, Olea europaea L., no Estado do Rio Grande do Sul. Ciência Rural, v.42, n.5, p.767769 , 2012. Available from: <http://dx.doi.org/10.1590/S010384782012005000022>. Accessed: Jun. 10, 2014. doi: 10.1590/ S0103-84782012005000022.

RICALDE, M.P.; GARCIA, F.R.M. Insetos e ácaros associados à cultura da oliveira na América do Sul. Revista de Ciências Ambientais, v.7, n.2, p.61-72, 2013.

SANTOS, S.A.P. et al. Artrópodes predadores associados à oliveira no Planalto Mirandês. In SIMPÓSIO NACIONAL DE OLIVICULTURA, 5., 2009, Santarém. Anais... Santarém: Associação Portuguesa de Horticultura, 2009. p.92-97.

SILVA, N.M. da. Levantamento e análise faunística de moscasdas-frutas (Diptera: Tephritidae) em quatro locais do Estado do Amazonas. 1993. 152f. Tese (Doutorado em Entomologia) Universidade de São Paulo, SP.

SILVEIRA NETO, S. et al. Manual de ecologia dos insetos. Piracicaba: Agronômica Ceres, 1976. 419p.

SPOONER-HART, R. et al. Field guide to olive pests, diseases and disorders in Australia. Avaliable from: $<\mathrm{http}$ ://agroquimicosgaspar. com.ar/wp-content/uploads/2011/12/07-153.pdf $>$. Accessed: Feb. $15,2014$.

THOMAZINI, M.J.; THOMAZINI A.P. de B.W. Diversidade de Abelhas (Hymenoptera: Apoidea) em Inflorescências de Piper hispidinervum (C.D.C.). Neotropical Entomology, v.31, p.2734, 2002. Available from: <http://dx.doi.org/10.1590/S1519566X2002000100004>. Accessed: Jan. 06, 2014. doi: 10.1590/ S1519-566X2002000100004.

VILLA, F.; OLIVEIRA, A.F. de. Origem e expansão da oliveira na América Latina. In: OLIVEIRA, A.F. de. et al. Oliveira no Brasil: tecnologias de produção. Belo Horizonte: Epamig, 2012. 772p.

Ciência Rural, v.45, n.12, dez, 2015. 